\title{
A Review of Demographic Trends for Texas and the United States
}

\author{
Russ Hodges, Texas State University \\ Emily Miller Payne, Texas State University \\ Emily Suh, Texas State University \\ Patricia Hernandez, Texas State University \\ $\mathrm{Na} \mathbf{W u}$, Texas State University \\ Amarilis Castillo, Texas State University
}

Tamara H. Shetron, Texas State University

\section{ABSTRACT}

This article provides a review of current and future demographic trends for Texas and the nation including the ongoing discrepancy between enrollment and retention/completion. Students entering postsecondary education embody America's growing diversity in language, ethnicity, age, gender, religion, sexual orientation, ability, and socioeconomic status. Demographic research findings support the importance of the role played by developmental educators in continuing to address the changing needs of students. Recommendations include the need for K-12 and postsecondary developmental educators to continue collaborating on college readiness initiatives, academic support services including career pathway advising, better alignment between 2- and 4-year institutions, developing cultural competence, and continuing research to improve support of underserved and diverse student populations.

emographic changes in the college-going population typically influence higher education policy and practice, thus it is imperative that educators inform themselves about demographic trends. This article offers a snapshot review of those demographic trends. Texas relies on our citizens to participate in the 21st century digital-age, knowledge-based economy. Educational attainment predictions estimate that $35 \%$ of U.S. jobs will require at least a bachelor's degree, and $30 \%$ will require some college or an associate's degree (Carnevale, Smith, \& Strohl, 2013). Nationally, healthcare support, community services and arts, and careers in the STEM field (science, technology, engineering, and mathematics) will be the fastest growing occupational clusters. Together, these occupational groups are expected to account for more than 5.3 million new jobs by 2022, about one-third of the total employment growth (U.S. Department of Labor, 2013; Carnevale et al., 2013). Texas, the second largest state in the U.S. in square miles and in population, has a gross domestic product (GDP) of \$1.6 trillion and is the second largest state economy in the U.S. (Forbes, 2017). Viewed globally, Texas ranks 11th for GPD just behind Canada (Perry, 2015). However, an undereducated workforce is a factor that can keep Texas from future economic growth. As early as 1997, Texas state demographer Steve Murdock posited that the Texas economic and political edge will decline by 2030 if educational attainment issues were not dealt with successfully (Tajalli \& Ortiz, 2017).

\section{Population Growth}

Even though the population of the U.S. has slowed in growth from 2015 to 2016 to just over 323 million people, a $0.7 \%$ increase, which is the lowest annual expansion in 80 years, some states (e.g. Utah, California, Washington, Arizona-among other Southern and Western states) including Texas have experienced substantial gains. Since 2000 , the Texas population has increased by $12.7 \%, 28$ million in 2016, second only to California's 39 million in total population (U.S. Census Bureau, 2016b).

Trends in immigration and birth rates also indicate that soon there will be no one majority ethnic group in the U.S. - that is, no one group that makes up more than $50 \%$ of the total population. In Texas, this demographic shift has already occurred. Hispanics currently make up 39\% of the general population, African-Americans 13\%, Asians $5 \%$, Native Americans 1\%, and White non-Hispanics $42 \%$ (U.S. Census Bureau, n.d.a).

The U.S. population has continued to grow older, with many states reaching a median age of over 37.9 years in 2016 (The Statistics Portal, 2018). In Texas, there is a noticeable difference in median age between White and Hispanic populations. According to the U.S. Census Bureau (n.d.a), the median age of White Texans in 2011 was 41, while the median age for Hispanics was 27 (Halebic, 2012). The young Hispanic population offsets the older White population in Texas making the median age of all Texans 33, lower than the U.S. average of 38 
years (U.S. Census Bureau, n.d.a). These demographic changes indicate that $\mathrm{K}-12$ and postsecondary education will be serving a growing majority-minority student population.

The gender ratio at birth in the U.S. is currently 105 males for 100 females; however, mortality at every age is higher for males. Within the U.S. population, this results in more males at younger ages and more females at older ages (Howden \& Meyer, 2011).

\section{K-12 Enrollment}

Nationally, approximately 50.7 million students entered public elementary and secondary schools for the Fall 2017 term (National Center for Education Statistics [NCES], n.d.). In Texas, in 2017, nearly 5.4 million students were enrolled (Texas Education Agency, 2017a). In 1940 , approximately $25 \%$ of the U.S. population 25 years old and over had completed high school compared to $88 \%$ in 2015 (Ryan \& Bauman, 2016). The Texas rate was a little better than the national average reaching 89\% (Texas Education Agency, 2017b). However, within the next decade, enrollment changes are predicted to vary by state with a few states experiencing swift public elementary and secondary school enrollment expansions greater than $15 \%$ (e.g. Colorado, Texas, and Utah) while others will experience enrollment losses of $10 \%$ or more (e.g. Maine, Michigan, New Hampshire, Connecticut, and Vermont) (NCES, 2018). These changes are closely tied to declining birth rates for Whites in the wake of the Baby Boom Echo and changes in populations by regions.

Texas K-12 enrollment increased almost $17 \%$ between 2006 and 2016 (Texas Education Agency, 2017a). In 2016, state totals for student demographics showed that $52 \%$ of students were Hispanic, 28\% White, 13\% Black, 4\% Asian, $0.4 \%$ Native American, and less than $0.1 \%$ Pacific Islander (Texas Education Agency, 2016).

\section{Postsecondary Enrollment}

In Fall 2017, total undergraduate enrollment in degree-granting postsecondary institutions reached 20.4 million students (U.S. Department of Education, 2017a). Yet, between 2011 and 2016 nationwide, the total number of enrolled college students fell every Fall. This trend will likely continue over the next 10 years (Hildreth, 2017). Texas enrollment for the Fall of 2017 in public and private universities was approximately 1.66 million students (Texas Higher Education Coordinating Board [THECB], 2018).

Demographic researchers have forecasted that between 2015 and 2026, part-time undergraduate enrollment will increase by $15 \%$, a faster increase than the $13 \%$ projected for full-time undergraduate enrollment
(McFarland et al., 2017). According to the THECB, postsecondary enrollment is expected to increase $8.3 \%$ between the years 2015 and 2020 at Texas public universities, and another 5.2\% from 2015-2025, and an additional 3.7\% between 2025-2030 (THECB, 2017).

Hispanics are the nation's largest minority group at 56.6 million, which is $17.6 \%$ of the U.S. population (U.S. Census Bureau, 2016a). The trend for Hispanic postsecondary enrollment is forecasted to continue between 2013-2024, with an increase of $25 \%$ nationally (Hussar \& Bailey, 2016), and by the middle of the 2020-2029 decade, 1 in 4 college graduates will be Hispanic (Bransberger \& Michelau, 2016). As for other groups, between 2013 and 2024, enrollment is predicted to increase for the following groups: White, 7\%; Black, 28\%; Asian and Pacific Islanders, 10\% (Hussar \& Bailey, 2016). Texas Hispanic enrollment in college in Fall 2017 was nearly equal to that of non-Hispanic Whites at $36.8 \%$ and $35.5 \%$ respectively. Black enrollment was $13.4 \%$, and other ethnicity categories totaled 14.3\% (THECB, 2018).

In 2015, 11.8 million students under age 25 and 8.1 million students 25 years old and over attended U.S. institutions of higher education. Both the number of students who are younger and older increased between 2000 and 2015 (U.S. Department of Education, 2017a). Aud et al. (2011) posited that between 2013 and 2020 , college enrollment is projected to increase $5 \%$ for 18 - to 24 -year-olds, $16 \%$ for 25 - to 34 -year-olds, and $17 \%$ for students 35 years old and older.

The current trend of females outnumbering males in enrollment and completion is projected to continue. In $2015,43 \%$ of women ages $18-24$ enrolled in undergraduate or graduate programs, compared with just $38 \%$ of men in the same age group (McFarland et al., 2017).

\section{Students First in Their Generation to Attend College}

Students who are first-generation to enroll in college in the U.S. comprise roughly $34 \%$ of the undergraduate population in 2011-12 (Postsecondary National Policy Institute, 2016). In 2012, the highest percentage of first-generation college students were White, followed by Hispanic, Black, Asians, and students of other races. In addition, a higher percentage of these students were native speakers of English (78\%) than of any other language (Redford \& Hoyer, 2017).

Students who are first-generation are not automatically presumed to be underprepared, but many come to college with limited background knowledge about the college culture, and students who are first-generation are less likely to enroll in higher education than students whose parents went to college (Engle \& Tinto, 2008; Ward, Siegel, \& Davenport, 2012). Previous research has 
found that students who are first-generation had higher rates of departure through their college years than their counterparts and were less likely to complete their degree programs in a timely manner (Ishitani, 2006). In fact, students who are low-income, first-generation were nearly four times more likely to leave college after their first year than those with neither of these two risk factors (Engle \& Tinto, 2008). Bowen, Chingos, and McPherson (2009) found that even when they controlled for students' test scores in reading and math, the graduation rate of students who are first-generation was $18 \%$ lower than that of college-goers who are non-first-generation. Studies have also indicated that students who are female first-generation are more likely to complete college than their male counterparts (DeAngelo, Franke, Hurtado, Pryor, \& Tran, 2011).

\section{Student Veterans}

Since the close of the Second World War and continuing through the Korean and Vietnam conflicts and the war in Iraq, the GI Bill has afforded veterans an opportunity to attend postsecondary programs for decades, easing the transition from military life to that of a civilian workforce (Cate, 2014). The Montgomery GI Bill, also referred to as the Servicemen's Readjustment Act of 1944, was signed by Franklin D. Roosevelt as a means of reintegrating veterans returning from World War II by affording them the opportunity to attain a college degree (Bennett, 1996). Student veteran is defined as "active-duty service members, reservists, members of the National Guard, and veterans" (Queen \& Lewis, 2014, p. 1). Ninety-six percent of postsecondary institutions for the 2012-13 academic year reported enrolling students who are veterans, and $82 \%$ of these institutions had a point of contact to serve their unique needs (Queen \& Lewis, 2014). In 2013, over 1 million student veterans used their $\mathrm{Gl}$ benefits to pursue postsecondary educational benefits, up from 500,000 in 2009, with expected enrollment estimated to increase by $20 \%$ over the next few years (VA Campus Toolkit Handout, 2014).

The Million Records Project (Cate, 2014) tracked 1 million student veterans between 2002 and 2010, and of those, $73 \%$ were male, $62 \%$ were first-generation, and $85 \%$ were non-traditional with many student veterans supporting families and juggling employment and school. Schuetze \& Slowey (2002), in their comparison of traditional and non-traditional students in higher education, defined as non-traditional those students who, for a variety of economic, cultural, and social reasons, were historically excluded from or underrepresentd in postsecondary education. Despite enrollment interruptions due to military obligations or challenges for those with service-connected disabilities, nearly $52 \%$ of student veterans within this study earned a degree or certificate within a 4- to 5-year period.

A greater percentage of Texas veterans are non-Hispanic Whites (66.9\%) and African Americans (13\%) compared to non-veterans $(45.7 \%$ and $11.8 \%$, respectively). Approximately $17 \%$ of the Texas veteran population is Hispanic (Texas Workforce Investment Council, 2016).
More veterans in Texas (28\%) have a bachelor's degree or higher or are continuing their postsecondary education compared to all other states and territories (25\%). Texas student veterans' enrollment is approximately $6 \%$ of students enrolled while the national average is $5 \%$ (U.S. Census Bureau, n.d.b).

Texas offers a unique educational benefit to Texas veterans called the Hazelwood Act. The Hazlewood Act provides up to 150 hours of coursework that exempts tuition and most fees at public institutions of higher education in Texas (Texas Veteran's Commission, 2018). The Act is an added incentive for veterans to pursue higher education in Texas. Student veterans form a part of the growing diversity on campuses across the nation and in Texas, and postsecondary institutions have a responsibility to assess these students' readiness for college-level work.

\section{English Language Learners}

With over one-quarter of the U.S. population being foreign-born or having at least one foreign-born parent, it is not surprising that the country is frequently referred to as a nation of immigrants. In fact, in 2013, foreign-born residents made up $13 \%$ of the U.S. population, a percentage reflecting a slow but steady increase (Trevelyan et al., 2016). Nearly half (46\%) of the nation's firstand second-generation immigrants are of Hispanic origin. Among the 60.6 million 2011 census respondents who reported speaking a language other than English at home, 35.2 million (58.2\%) reported speaking English "very well" as opposed to $15.4 \%$ and $7.0 \%$ who reported speaking English "not well" or "not at all respectively" (Ryan, 2013).

Students who speak a language other than English at home are tested upon their entry into the public school system and may receive special services for English Language Acquisition (commonly referred to as English as a Second Language [ESL]). While these students attend ESL classes or receive language monitoring, they are referred to as English Learners (ELs) or English Language Learners (ELLs). During the 2014-2015 academic year, an estimated 4.6 million students (9.4\% of all public school students) nationally participated in language assistance programs (McFarland et al., 2017). These students speak over 400 different languages although more than three-quarters spoke Spanish as a first language in 2014-2015; the next most common non-English languages were Arabic, Chinese, and Vietnamese (U.S. Department of Education, 2017b).

Texas has a long history of Hispanic-background residents and a checkered but proud Spanish and English linguistic history (Valencia, 2000). Between 2005 and 2013, Texas experienced a decline in Latin America-born migrants, but this decrease was nearly offset by increases in Asian-origin migration; currently, Latino birthrates continue to outpace those of other ethnic groups (White et al., 2015). Approximately one out of every six Texas residents was born in a foreign country; based on size and composition, the state's foreign-born population is more international than at any time in its history (White et al., 2015). 
In 2009, 4.8 million children (35.4\%) in Texas K-12 public schools spoke a language other than English at home (Aud et al., 2011). In line with the state's ethnic makeup, the majority (91\%) of these students spoke Spanish; making up the next largest group, Asian or Pacific Islander languages were spoken at home by approximately $5 \%$ of students (Aud et al., 2011). Although many children spoke a language other than English at home, only $18.8 \%$ of Texas' multilingual student population receives bilingual or ESL instructional services (Texas Education Agency, 2017c), and only 8.5\% are classified as Limited English Proficient (Aud et al., 2011). The majority of Texas' multilingual students either receive monitoring or do not receive additional support. Many of these students are born in the U.S. and are considered English proficient before graduation (Cortez \& Villarreal, 2009). In fact, the Hispanic student graduation rate has increased at a rate exceeding increases in the group's population gains (Bransberger \& Michelau, 2016).

Although the National Center for Educational Statistics tracks K-12 students' language backgrounds and postsecondary student racial/ethnic background, reports like McFarland et al.'s The Condition of Education (2017) or even specially commissioned reports on access in higher education do not include demographic information regarding postsecondary students' home language(s) (McFarland et al., 2017; Ross et al., 2012). The lack of national data on college students' language background may be due in part to the absence of federal government resources for tracking and serving linguistically diverse students in college and also to college entrance requirements which include certain levels of English language proficiency. As a result, limited data track students' postsecondary enrollment and competition by language background.

Texas is educating a growing number of multilingual students. The state faces many challenges in meeting the linguistic needs and honoring the cultural and linguistic resources these students bring to their classrooms; however, these challenges do not end within the K-12 system. Although the vast majority of the state's multilingual students no longer require special services by the time they reach college, such students perform better and are retained at higher rates when their college classes and campuses honor their multilingualism and multiculturalism (Castellanos \& Gloria, 2007; Oseguera, Locks, \& Vega, 2008; Tierney \& Jun, 2001).

\section{Student College Readiness Estimates}

Projections of college readiness is a complicated student characteristic to assess. Whether states rely on a single assessment instrument for placement of students who are deemed college ready and placed in college credit courses, or on multiple indicators of preparedness, many other readiness factors must be considered: point of entry (2-year or 4- year institution, public or private institution), selectivity of the institution, and students' academic goals and fields of study are only a few factors to consider in the projection of college readiness. Interestingly, past research has indicated that students' academic achievement by $8^{\text {th }}$ grade is one of the best predictors of college readiness-even more so than high school achievement (ACT, 2008).

Complication of developmental education student enrollment as a proxy for college readiness is further exacerbated by lack of standardized assessment, placement, outcomes, and instructional practices. Aud et al. (2011) reported that $36 \%$ of students overall and $42 \%$ of students in their first year in community college take at least one developmental course. More recently, Complete College America's (2012) Remediation: Higher Education's Bridge

to Nowhere reported that more than $50 \%$ of students entering 2-year colleges and nearly $20 \%$ of those entering 4 -year universities are placed in developmental courses. Thus, using multiple college readiness indicators and those specific to a particular region or institution is best when assessing college readiness (Bailey \& Dynarski, 2011).

Since Fall 2013, placement into developmental courses in Texas is made based upon results of the Texas Success Initiative Assessment (TSIA) with exemptions made based upon a student's performance on SAT, ACT, Texas Assessment of Academic Skills (TAAS), Texas Learning Index (TLI), Texas Assessment of Knowledge and Skills (TAKS), and State of Texas Assessment of Academic Readiness (STA$A R$ ) as well as exemptions for transfer students and veterans. Currently, approximately $60 \%$ of Texans applying to 2-year schools in Texas and approximately $18 \%$ applying to 4-year schools in Texas are not college ready. Success rates for completion of developmental courses for a 2013 cohort were $37 \%$ in reading, $31 \%$ in writing, and $15 \%$ in math (THECB, 2018). Graduation rates for students in 2-year colleges who placed into developmental education are just 36\% after three years of attendance compared to $57 \%$ of students who enter college-ready (THECB, 2018).

\section{First-Year Retention and Persistence}

Large numbers of students are not returning to college after their first year. The National Student Clearinghouse Research Center (NSCRC, 2017) defined the college student persistence rate as the percentage of students who return to college at any institution for their second year, while the retention rate is defined as the percentage of students who return to the same institution for their second year. According to NSCRC (2017), the overall persistence rate for first-time students has increased by $1.9 \%$ between 2009 and 2015, while the retention rate 
has remained approximately 13 points lower than the persistence rate. Of all first-time students who started in Fall 2015, 73.4\% returned to college in Fall 2016 with 61.1\% returning to the same institution. Thus, about one in eight students who start college in any Fall term transfers to a different institution by the following Fall (NSCRC, 2017). Between 2009 and 2015, persistence rates for students age 20 or under at college entry were $78 \%$. For students age $20-24$ at entry, the persistence rate was $57.8 \%$, and for students over 24 at college entry, the persistence rate was $52.7 \%$ (NSCRC, 2016). Student enrollment for the second year is now a prime indicator of college completion (NSCRC, 2017). Unfortunately, retention rates for minority students do not match enrollment rates. In 2013, the dropout rate for Hispanics was $13 \%$, higher than the dropout rates for White students at $5 \%$ and Black students at $7 \%$ (NCES, n.d.).

In Texas, first-year retention (using the federal definition for retention) in public institutions falls below the national levels in public postsecondary institutions. Firstyear 2015 retention for 2-year public colleges was $52.3 \%$, compared to the national average of 53.9\%. First-year 2015 retention for 4-year public colleges was $77 \%$ compared to a national average of $80.5 \%$ (National Center for Higher Education Management Systems [NCHEMS], 2018).

\section{Degree Completion}

The country's college degree attainment has steadily declined compared to other nations. In 1990, the U.S. ranked first in the world in 4-year degree attainment among adults 25 to 34 years of age; however, today the U.S. ranks 12th (Ryan \& Bauman, 2016). While half of all people from high-income families from the U.S. have a bachelor's degree by age 25, just 1 in 10 people from low-income families do (Bailey \& Dynarski, 2011). Degree completion predictions are most interesting as the total number of associate's degrees is projected to increase 14\% between Fall 2013 and Fall 2024 (Hussar \& Bailey, 2016). The lower cost of attending community college is likely driving this rapid increase. A more modest increase of $10 \%$ will occur for bachelor's degree completions over this same period (Hussar \& Bailey, 2016).

Texas has made progress - to some degreeincreasing certificate and degree completion of its citizens based on results cited in Closing the Gaps by 2015 (THECB, 2017). In the year 2015, postsecondary institutions awarded approximately 250,000 bachelor's degrees, associate degrees, and certificates-nearly 130,000 more than in 2000 (THECB, 2016).

Texas has a 6-year graduation rate from 4-year institutions of approximately $53 \%$, which places Texas 31 st in the nation for graduation completion compared with the top state rate in Massachusetts of $71 \%$ and the lowest state rate of $40 \%$ in Alaska. Texas students have a $6.9 \%$ graduation rate from 2-year schools (THECB, 2018).

Across the country, postsecondary education is under pressure from legislatures and taxpayers to increase graduation rates, and Texas is no exception. In the current state plan for 2- and 4-year colleges, 60×30 Higher Education Plan (60x30TX), the primary focus is on not only increasing completion but also doing so in fewer years with fewer course credits and culminating in degrees that are aligned with labor market demands (THECB, 2018).

\section{Recommendations}

The traditional model of college is changing, especially the full-time residential model (Postsecondary National Policy Institute, 2016; Van Der Werf \& Sabatier, 2009). What opportunities exist to support students' access and success to an evolving higher education system based on demographic prediction trends for the state of Texas? A list of recommendations follows to guide researchers, policymakers, and practitioners.

\section{Helping More Students Become College-Ready}

The 60x30TX higher education strategic plan's overarching goal states, "By 2030 , at least $60 \%$ of Texans ages 25-34 will have a certificate or degree" (THECB, 2018). The plan is designed to ensure college readiness in Texas is competitive nationally. To meet this goal, Texas students should be college- and career-ready by high school graduation and preferably assessed for college readiness beginning no later than 10th grade. If not, transition programs, early boot camps, and other college readiness interventions should be implemented. K-12 and postsecondary collaborators should also continue to promote early college- and career-readiness programs allowing students to participate in early college high school programs earning up to 60 hours of college credit by the time they graduate.

\section{Advising and Designing Guided Pathways}

Continued advising in K-12 and postsecondary education should emphasize the labor market growth areas for students such as in health care and STEM professions. With the charge to streamline the process of moving students into career-oriented certification and degree pathway programs, K-12 and colleges should continue to collaborate on academic and career advising before students reach postsecondary education. In fact, students should prepare to make career choices in junior high and high school.

Many community colleges are redesigning their program offerings to allow students to select from a much narrower sequence of options. These highly structured guided pathways require more intrusive advising and integrated support services to be afforded to students. Guided pathways provide students with a clear roadmap to ontime completion, offering personalized guidance to help students stay on track. Some pathway models include features such as block scheduling and prescribed curricula (Bailey, Jaggers, \& Jenkins, 2011).

\section{Better Alignment Between 2- and 4-Year Programs}

While the majority of community college students indicate they want to earn a bachelor's degree or higher (81\%), only $33 \%$ actually transfer to a 4-year institution within 6 years (Jenkins \& Fink, 2016). Of those 33\% who do transfer to 4 -year colleges, $42 \%$ complete a bachelor's degree within 6 years (Jenkins \& Fink, 2016). One possible reason for this low transfer rate is that many 2-and 4-year programs have established transfer agreements, but Texas statewide policy and oversight needs to assure that 
transfer students can avoid retaking the same courses. In some cases, non-core community college courses are often accepted but not as credit toward a major (Jenkins \& Fink, 2016).

\section{Meeting the Changing Needs of Students}

College students often work while in college to support themselves, to support families (taking care of their children or as caregivers for parents and grandparents), and come from low-income backgrounds more so than in earlier generations. Currently, only half of today's students fit into the traditional age cohort between 17 and 21 years of age (Bill \& Melinda Gates Foundation, n.d.a). Students are also more mobile as more than half of bachelor's degree recipients attend more than one institution, many stopping out for periods of time, before graduating (Van Der Werf \& Sabatier, 2009; Wexler, 2016). For this reason, community colleges will continue to appeal to many students, especially part-time students.

Many colleges without strong identities or brand names will need to transform to appeal to more part-time, adult, and diverse students, especially those wanting to learn primarily through digital and hybrid technology formats (Van Der Werf \& Sabatier, 2009). With nearly 3 million students currently enrolled in fully online degree programs and 6 million taking at least one online course as part of their degree program, online education is in demand (Open Education Database, n.d.). Online courses offer many benefits including more flexible learning approaches such as active- and project-based learning, access to courses that are over capacity, and to accommodate students who live in rural areas, those with special needs, and veterans currently serving in the military. Yet, students should have strong self-regulatory abilities and be self-directed to persist in online courses.

\section{Helping Underserved Students}

For Texas students who come to college underserved by their previous high school experiences, postsecondary education researchers and practitioners should continue to focus research efforts on how best to prepare students academically. While studies (Aud et al., 2011; Bailey, Jaggers, \& Jenkins, 2011; Goudas \& Boylan, 2012) have found the use of single standardized placement assessments and stand-alone remedial courses often ineffective, researchers from Texas postsecondary institutions should continue to investigate the effectiveness of the Texas Success Initiative Assessment (TSIA). It is important to acknowledge that the College Board's 2016 validity study of the TSIA, conducted to establish the predictive placement validity of each of the tests, confirmed the reading and mathematics benchmarks while informing the recalibration of the writing score (College Board, 2016).
Postsecondary institutions should continue to implement innovations to support students needing basic skill instruction by adopting new reforms - such as compressed, integrative, contextualized, and linked course formats. For example, linked courses, often referred to as learning communities, allow cohorts of students to co-enroll in two or more courses (e.g., pairing developmental mathematics with a student success course integrating assignments and assessments). Additional hybrid approaches combine face-to-face and digital modular curriculum components. Importantly, colleges should offer an array of high-impact supports in tandem with coursework that span students' academic careers offered during the day, evening, and weekend hours (e.g., guided pathway advising, mentoring, coaching, counseling, and tutoring) (Bailey \& Dynarski, 2011; College Board, n.d.; MDRC, 2017; Tajalli \& Ortiz, 2017).

The THECB has funded several initiatives to improve delivery of developmental education programs and services. Among examples of THECB-initiated innovations are the Comprehensive College Readiness and Success Models for $60 \times 30$ (CRSM) that support scaling comprehensive strategies to meet the goals of the $60 \times 30$ plan (THECB, 2016) and the Comprehensive Student Success Program (CSSP) (THECB, 2018). One programmatic innovation mandated by the $85^{\text {th }}$ Texas Legislature to commence in 2018 , for example, is the new Texas corequisite initiative in which students who enter with TSIA scores within an institutionally-determined "bubble range" (Daugherty, Gomez, Carew, Mendoza-Graf, \& Miller, 2018, p. 7) are eligible to enroll in a developmental course or non-course-based option along with the matching college-credit course. The corequisite model may show promise, but that, like many other initiatives as mentioned above, requires careful study. The corequisite model in Texas is being implemented in a phased-in initiative with institutions through 2020 (HB2223, 2017).

\section{Developing Cultural Competence}

Given changing demographics in Texas and the nation, educators should advocate for institutions to commit to supporting access to higher education for all diverse groups of students. Specifically, retaining students begins with an appreciation for the intersectional nature of the students' postsecondary experiences which are influenced by their academic preparation (Swail, Redd \& Perna, 2003), the racialized contexts of higher education institutions (Hurtado, Milem, Clayton-Pederson, \& Allen, 1998), campus climate (Torres, 2006), and their outsideof-school roles and responsibilities (Sáenz, Bukoski, Lu, \& Rodriguez, 2013), among other factors. Importantly, as Hurtado and Ponjuan (2005) noted, "Actual experiences in 
the college environment play a more important role than student background in predicting perceptions of a hostile climate for diversity" (p. 244). Developmental educators and administrators should reaffirm their commitment not only to crafting diversity statements but also to embedding diversity into students' experiences throughout institutions of higher learning.

Colleges should become more accessible by not only being more affordable but also by creating a college-going culture by adopting promising practices in recruiting and retaining students of color with special emphasis on males, students first in their families to attend college, and adult students returning to college for new career options and enhancement. Additionally, efforts must continue to serve student veterans and their families, students with disabilities, students that identify as LGBTQIAt, and those students gaining English proficiency.

Texas educators should enhance their cultural awareness to foster learning environments that promote an ethical responsibility for self and others, encourage meaningful discourse where multiple ways of knowing are seen as valid, and use sensitive techniques when teaching and assessing learning. Importantly, Texas educators of the 21st century should support students' intellectual development to learn and excel within a diverse educational community and to support the development of students' social and interpersonal skills that are needed to interact effectively within such a community.

Students entering postsecondary education embody America's growing diversity in language, ethnicity, age, gender, religion, sexual orientation, ability, and socioeconomic status, among others. Throughout the professions' history, developmental educators and learning assistance professionals have been at the forefront in creating access, developing new pedagogies for teaching, and innovating academic support programs designed to support a diverse array of college students. Texas educators should address students' needs with changes in campus infrastructure, enrollment planning, and curricula that fits the labor market needs and changing demographics. The discrepancy between enrollment rates and retention and completion rates highlights this critical call for continued interventions and use of promising practices that are student-centric, highly personalized for each learner, and more productive to deliver dramatically better results at the same or lower cost. The future of Texas depends on it.

\section{References}

ACT. (2008). The forgotten middle: Ensuring that all students are on target for college and career readiness before high school. Retrieved from https://www.act.org/content/dam/act/ unsecured/documents/ForgottenMiddle.pdf

Aud, S., Hussar, W. J., Kena, G., Bianco, K., Frohlich, L., Kemp, J., \& Tahan, K. (2011). The condition of education 2011 (NCES 2011-033). U.S. Department of Education, National Center for Education Statistics. Washington, DC: U.S. Government Printing Office. Retrieved from https://nces.ed.gov/ pubs2011/2011033.pdf
Bailey, M. J., \& Dynarski, S. M. (2011). Gains and gaps: Changing inequality in U.S. college entry and completion (Working Paper 17633). Cambridge, MA: National Bureau of Economic Research. Retrieved from http://www.nber.org/papers/w17633

Bailey, T. R, Jaggers, S. S, \& Jenkins, D. (2011). Introduction to CCRC assessment evidence series (Assessment of Evidence Series). New York, NY: Community College Research Center, Columbia University. Retrieved from https://ccrc.tc.columbia.edu/ media/k2/attachments/introduction-ccrcassessment-evidence.pdf

Bennett, M. (1996). When dreams came true: The GI Bill and the making of modern America. McLean, VA: Brasseys.

Bill \& Melinda Gates Foundation. (n.d.a). Postsecondary success: College students in Texas. Retrieved from https://postsecondary.gatesfoundation.org/ college-students-texas-infographic/

Bill \& Melinda Gates Foundation. (n.d.b). Postsecondary success: Today's college students infographic. Retrieved from https://postsecondary. gatesfoundation.org/areas-of-focus/incentives/ policy-advocacy/advocacy-priorities/america100-college-students/

Bowen, W. G., Chingos, M. M., \& McPherson, M. S. (2009). Crossing the finish line: Completing college at America's public universities. Princeton, NJ: Princeton University Press.

Bransberger, P., \& Michelau, D. K. (2016). Knocking at the college door: Projections of high school graduates, December 2016 (9th ed.). Boulder, CO: Western Interstate Commission for Higher Education. Retrieved from https://static1.squarespace. com/static/57f269e19de4bb8a69b470ae/t/5 8d2eb93bf629a4a3878ef3e/1490217882794/ Knocking2016FINALFORWEB-revised021717.pdf

Carnevale, A. P., Smith, N., \& Strohl, J. (2013). Recovery: Job growth and education requirements through 2020. Retrieved from https://cew-7632.kxcdn.com/wp-content/ uploads/2014/11/Recovery2020.FR_.Web_.pdf

Castellanos, J., \& Gloria, A. M. (2007). Research considerations and theoretical application for best practices in higher education: Latina/os achieving success. Journal of Hispanic Higher Education, 6(4), 378-396. https://doi. org $/ 10.1177 / 1538192707305347$

Cate, C. A. (2014). Million records project: Research from student veterans of America. Student Veterans of America, Washington, DC. Retrieved from http://studentveterans.org/images/Reingold_ Materials/mrp/download-materials/mrp_Full_ report.pdf

College Board (2016). The predictive placement validity study of the Texas Success Initiative Assessment (TSIA). Retrieved from http://www.thecb.state.tx.us/reports/ PDF/9567.PDF?CFID=76060667\&CFTOKEN=51037878 
College Board. (n.d.). Trends in higher education: Educational attainment by race/ethnicity and gender 1973-2009. Retrieved from https://trends. collegeboard.org/education-pays/figures-tables/ educational-attainment-race-ethnicity-andgender-1973-2009

Complete College America. (2012). Remediation: Higher education's bridge to nowhere. Retrieved from https://postsecondary.gatesfoundation.org/ wp-content/uploads/2014/10/CCA-RemediationBridge-to-No-Where.pdf

Cortez, A., \& Villarreal, A. (2009). Education of English language learners in U.S. and Texas schools: Where we are, what we have learned and where we need to go from here. San Antonio, TX: Intercultural Development Research Association. Retrieved from https://files.eric.ed.gov/fulltext/ED505913.pdf

Daugherty, L., Gomez, C.J., Carew, D. G., Mendoza-Graf, A, \& Miller, T. (2018). Designing and implementing corequisite models of developmental education: Findings from Texas community colleges. Rand Corporation. Retrieved from https://www.rand. org/pubs/research_reports/RR2337.html

DeAngelo, L., Franke, R., Hurtado, S., Pryor J. H., \& Tran, S. (2011). Completing college: Assessing graduation rates at four-year institutions. Los Angeles, CA: Higher Education Research Institute, UCLA. Retrieved from https://heri.ucla.edu/DARCU/CompletingCollege2011.pdf

Engle, J., \& Tinto, V. (2008). Moving beyond access: College success for low-income, first-generation students. Washington, DC: Pell Institute for the Study of Opportunity in Higher Education. Retrieved from https://files.eric.ed.gov/fulltext/ED504448.pdf

Forbes. (2017, November). Best states for business: Texas. [online] Author. Retrieved from https://forbes. $\mathrm{com} /$ places/tx/

Goudas, A. M., \& Boylan, H. R. (2012). Addressing flawed research in developmental education. Journal of Developmental Education, 36(1), 2-4. Retrieved from https://eric.ed.gov/?id=EJ1035669

Halebic, M. (2012). Texas population growth, projections, and implications [PowerPoint presentation], SABER Research Institute. Retrieved from http://www.sahcc.org/wp-content/uploads/ Texas-Population-Growth-Projections-andImplications.pdf

H.B. $2223 \S 51.336$ (2017). Retrieved from Texas State Legislature Online: https://capitol.texas.gov/ BillLookup/History.aspx?LegSess=85R\&Bill=HB2223

Hildreth, B. (2017, July). U.S. colleges are facing a demographic and existential crisis. Retrieved from https://www.huffingtonpost.com/entry/ us-colleges-are-facing-a-demographic-andexistential_us_59511619e4b0326c0a8d09e9

Howden, L. M., \& Meyer, J. A. (2011). Age and sex composition: 2010 Census briefs (C2010BR-03). U.S. Department of Commerce, U.S. Census Bureau. Retrieved from http://www.census.gov/prod/ cen2010/briefs/c2010br-03.pdf
Hurtado, S., Milem, J. F., Clayton-Pederson, A. R., \& Allen, W. R. (1998). Enhancing campus climates for racial/ ethnic diversity: Educational policy and practice. The Review of Higher Education, 21(3), 279-302. Retrieved from http://www.mofet.macam. ac.il/rashut/hafacha/walterallen/Documents/ EnhancingCampusClimatesforRacialEthnicDiversity.pdf

Hurtado, S., \& Ponjuan, L. (2005). Latino educational outcomes and the campus climate. Journal of Hispanic Higher Education, 4(3), 235-251. doi: $10.1177 / 1538192705276548$

Hussar, W. J., \& Bailey, T. M. (2016). Projections of educational statistics to 2024 (NCES 2016-013). U.S. Department of Education, National Center for Education Statistics. Washington, DC: U.S. Government Printing Office. Retrieved from https://nces. ed.gov/pubs2016/2016013.pdf

Ishitani, T. T. (2006). Studying attrition and degree completion behavior among first-generation college students in the U.S. Journal of Higher Education, 5, 861-885. doi: 10.1353/jhe.2006.0042

Jenkins, D., \& Fink, J. (2016). Tracking transfer: New measures of institutional and state effectiveness in helping community college students attain bachelor's degrees. Retrieved from https://ccrc. tc.columbia.edu/publications/tracking-transferinstitutional-state-effectiveness.html

McFarland, J., Hussar, B., Brey, C. D., Snyder, T., Wang, X., Wilkinson-Flicker, S., . . Hinz, S. (2017). The condition of education 2017 (NCES 2017-144). U.S. Department of Education, National Center for Education Statistics. Washington, DC. Retrieved from https://nces.ed.gov/pubs2017/2017144.pdf

MDRC. (2017, June). Looking forward: Promising reforms in developmental education. Retrieved from https://www.mdrc.org/sites/default/files/ LookingForward_DevEducation_2017.pdf

National Center for Education Statistics (NCES). (n.d.). Fast facts. Retrieved from https://nces.ed.gov/ fastfacts/display. asp?id=372

National Center of Education Statistics (NCES). (2018). Elementary and secondary enrollment. Retrieved from https://nces.ed.gov/programs/coe/indicator_cga.asp

National Center for Higher Education Management Systems (NCHEMS). (2018). First-year retention rates: Firsttime college freshmen returning their second year. Retrieved from http://www.higheredinfo. org/dbrowser/index.php?measure $=92$

National Student Clearinghouse Research Center (NSCRC). (2016). Persistence and retention. Retrieved from https://nscresearchcenter.org/snapshotreportpersistenceretention22/

National Student Clearinghouse Research Center (NSCRC). (2017). First-year persistence and retention. Retrieved from https://nscresearchcenter.org/ snapshotreport28-first-year-persistence-andretention/ 
Open Education Database. (n.d.). 10 advantages to taking online classes. Retrieved from https://oedb. org/ilibrarian/10-advantages-to-taking-onlineclas2009ses/

Oseguera, L., Locks, A. M.,, \& Vega, I. I. (2009). Increasing Latina/o students baccalaureate attainment: A focus on retention. Journal of Hispanics in Higher Education, 8(1), 23-53. https://doi. org/10.1177/1538192708326997

Perry, M. J. (2015, June). If New York is Spain, and California, Brazil, what is Texas? Newsweek. Retrieved from http://www.newsweek.com/ if-new-york-spain-and-california-brazil-whattexas-344702

Postsecondary National Policy Institute. (2016). Factsheets: First generation students. Retrieved from https://pnpi.org/ factsheets/first-generation-students/

Queen, B., \& Lewis, L. (2014). Services and support programs for military service members and veterans at postsecondary institutions, 2012-2013. U.S. Department of Education. Washington, DC: National Center of Education Statistics. Retrieved from https://nces.ed.gov/pubs2014/2014017.pdf

Redford, J., \& Hoyer, K. M. (2017, September). Firstgeneration and continuing-generation students: A comparison of high school and postsecondary experiences. Stats in Brief, U.S. Department of Education. Retrieved from https://nces.ed.gov/ pubs2018/2018009.pdf

Ross, T., Kena, G., Rathbun, A., Kewal Ramani, A., Zhang, J., Kristapovich, P., \& Manning, E. (2012). Higher education: Gaps in access and persistence study. (NCES 2012-046). U.S. Department of Education, National Center for Education Statistics. Washington, DC. Retrieved from https://nces. ed.gov/pubs2012/2012046.pdf

Ryan, C. (2013). Language use in the U.S.: 2011. (Report No. ACS-22). Retrieved from https://www.census. gov/library/publications/2013/acs/acs-22.html

Ryan, C. L., \& Bauman, K. (2016, March). Educational attainment in the United States: 2015 (Issue Brief. No. P20-578). Retrieved from https://www.census.gov/ content/dam/Census/library/publications/2016/ demo/p20-578.pdf

Sáenz, V. B., Bukoski, B. E., Lu, C., \& Rodriguez, S. (2013). Latino males in Texas community colleges: A phenomenological study of masculinity constructs and their effect on college experiences. Journal of African American Males in Education, 4(2), 82-102. Retrieved from http://journalofafricanamericanmales.com/wpcontent/uploads/2013/11/Saenz-et-al-2013.pdf

Schuetze, H.G., \& Slowey, M. (2002). Participation and exclusion: A comparative analysis of nontraditional students and lifelong learners in higher education. Higher Education (44), 309-327. https://doi.org/10.1023/A:1019898114335
The Statistics Portal. (2018). Median age of the resident population of the United States from 1960 to 2017. Retrieved from https://www.statista. com/statistics/241494/median-age-of-the-uspopulation/

Swail, W. S., Redd, K. E., \& Perna, L. W. (2003). Retaining minority students in higher education: $A$ framework for success. (ASHE-ERIC Higher Education Report (Vol. 30, No 2). Retrieved from http://www.educationalpolicy.org/pdf/Swail_ Retention_Book.pdf

Tajalli, H., \& Ortiz, M. (2017). An examination of Hispanic college enrollment and graduation: Has the Texas Closing the Gaps plan been successful? Journal of Latinos and Education. https://doi.org/10.1080/1 5348431.2017.1348301

Texas Education Agency. (2016). Texas academic performance report 2015-16 state performance. Retrieved from https://rptsvr1.tea.texas.gov/ perfreport/tapr/2016/state.pdf

Texas Education Agency. (2017a). 2017-2018 Texas education data standards. Retrieved from https://www.texasstudentdatasystem.org/TSDS/ TEDS/TEDS_Latest_Release/

Texas Education Agency. (2017b). Secondary school completion and dropouts in Texas public schools, 2015-16 (Document No. GE17 601 13). Austin, TX: Author. Retrieved from https://tea.texas.gov/ acctres/dropcomp_index.html

Texas Education Agency. (2017c). Enrollment in Texas public schools 2016-2017. Retrieved from https://tea.texas.gov/acctres/enroll_2016-17.pdf

Texas Higher Education Coordinating Board (THECB). (2016). Closing the gapsfinal progress report. Retrievedfrom http://www.thecb.state.tx.us/reports/PDF/8138. PDF?CFID $=69416901 \&$ CFTOKEN $=35084421$

Texas HigherEducation Coordinating Board(THECB). (2017). Enrollment forecast 2017-2030. Retrieved from http://www.thecb.state.tx.us/reports/PDF/9111. PDF?CFID $=78947936 \&$ CFTOKEN $=44475344$

Texas Higher Education Coordinating Board(THECB). (2018). 2018 Texas public higher education almanac: A profile of state of institutional performance and characteristics. Retrieved from http://www. thecb.state.tx.us/index.cfm?objectid=629F37F0861F-11E8-AE230050560100A9

Texas Veteran's Commission. (2018). Texas Hazlewood Act News. Retrieved from https://www.tvc.texas. gov/education/hazlewood-act/

Texas Workforce Investment Council. (2016). Veterans in Texas: A demographic study. Retrieved from https:/gov.texas.gov/uploads/files/organization/ twic/VeteransUpdate_Summary.pdf

Tierney, W. G., \& Jun, A. (2001). A university helps prepare low income youths for college: Tracking school success. Journal of Higher Education, 72(2), 205-225. Retrieved from https://www.jstor.org/ stable/2649322?origin=JSTOR 
Torres, V. (2006). Bridging two worlds: Academia and Latina/o identity. In J. Castellanos, A. Gloria, \& M. Kamimura (Eds.), The Latina/o pathway to the Ph.D.: Abriendo caminos (pp. 135-147). Virginia: Stylus.

Trevelyan, E., Gambino, C., Gryn, T., Larsen, L., Acosta, Y., Grieco, E., Harris, D., \& Walters, N. (2016). Characteristics of the U.S. population by generational status: 2013. Washington, D.C.: U.S. Census Bureau Retrieved from https://www.census.gov/content/dam/ Census/library/publications/2016/demo/ P23-214.pdf

U.S Census Bureau. (n.d.a). Quick facts: Texas. Retrieved from https://www.census.gov/quickfacts/fact/ table/TX/SEX255216\#viewtop

U.S. Census Bureau. (n.d.b). Veteran statistics: Texas. Retrieved from https//www2.census.gov/library/ visualizations/2015/comm/vets/tx-vets.pdf

U.S. Census Bureau. (2016a). Facts For Figures: Hispanic heritage month 2016. Retrieved from https://www.census.gov/newsroom/facts-forfeatures/2016/cb16-ff16.html

U.S. Census Bureau. (2016b). Utah is nation's fastestgrowing state. Retrieved from https://census.gov/ newsroom/press-releases/2016/cb16-214.html

U.S. Department of Education. (2017a). Fast facts: Back to school statistics. Retrieved from https://nces. ed.gov/fastfacts/display.asp?id=372

U.S. Department of Education, Office of English Language Acquisition. (2017b). Our nation's English Learners: What are their characteristics. Retrieved from https://www2.ed.gov/datastory/ el-characteristics/index.html

U.S. Department of Labor. (2013). Occupational employment projections to 2022. Retrieved from https://www.bls.gov/opub/mlr/2013/article/ occupational-employment-projections-to-2022.htm

VA Campus Toolkit Handout. (April, 2014). Veterans administration campus toolkit handout:

Characteristics of student veterans. Retrieved from http://www.mentalhealth.va.gov/studentveteran/ docs/ed_todaysStudentVets.html

Valencia, R. R. (2000). Inequalities and the schooling of minority students in Texas: Historical and contemporary conditions. Hispanic Journal of Behavioral Sciences, 22(4), 445-459. https://doi. org/10.1177/0739986300224005

Van Der Werf, M. \& Sabatier, G. (2009). The college of 2020: Students. Retrieved from http://www. achsnatl.org/meeting 2011/The_College_ of $>2020$-Students.pdf

Ward, L., Siegel, M. J., \& Davenport, Z. (2012). Firstgeneration college students: Understanding and improving the experience from recruitment to commencement. San Francisco, CA: Jossey-Bass.

Wexler, E. (2016, May). The ignored graduates. Retrieved from https://www.insidehighered. com/news/2016/05/05/stories-students-notcounted-federal-graduation-rates
White, S., Potter, L. B., You, H., Valencia, L., Jordan, J. A., \& Pecotte, B. (2015). The foreign-born population in Texas: Sources of growth: Office of the State Demographer. Retrieved from http://demographics.texas.gov/Resources/ Publications/2015/2015_10_07_ForeignBorn.pdf 